\title{
WORK ENGAGEMENT AND ORGANISATIONAL CITIZENSHIP BEHAVIOUR AMONG NURSES IN LAUTECH HOSPITAL, OSOGBO, OSUN STATE
}

\author{
DOI: 10.36108/ljerhrm/2202.03.0150
}

\author{
OJO, Solomon ${ }^{1}$, ABDULAZEEZ, Olawale Abdulmaleek ${ }^{2}$, OLUWOLE, Temiloluwa Hannah ${ }^{3}$ \\ Department of Human Resource Development ${ }^{1,2} \& 3$ \\ Osun State University Osogbo
}

\begin{abstract}
This study examined the relationship between work engagement and organisational citizenship behaviour among Nurses in LAUTECH Hospital, Osogbo, Osun State. The study was a survey which employed Expost-Facto survey design. A total of 150 Nurses were selected from LAUTECH Hospital, Osogbo in which 70 (46.7\%) were male while 80 (53.3\%) were female. Questionnaire format was employed for data collection. Collected data were analyzed by both descriptive and inferential statistics, using the application of statistical package for social sciences (SPSS) version 21.0. The results showed that there was a significant positive relationship between work engagement and organisational citizenship behaviour among Nurses in Lautech Hospital, Osogbo, Osun State [ $r$ $\left.(148)=.26^{* *} P<.01\right]$, there was a significant positive relationship between work engagement and altruism among Nurses in Lautech Hospital in Osogbo, Osun State [r $(148)=.13 * *, P<.01]$,there was a significant positive relationship between work engagement and sportsmanship among Nurses in Lautech Hospital, Osogbo, Osun State [r (148) =.74**, P<.01], that there was a significant positive relationship between work engagement and conscientiousness among Nurses in Lautech Hospital, Osogbo, Osun State $[r(148)=.23 *, P<.01]$,there was a significant positive relationship between work engagement and civic virtue among Nurses in Lautech Hospital at Osogbo, Osun State $\left[r(148)=.36^{*}, P<.05\right]$. It was concluded therefore that work engagement was significantly related to organisational citizenship behaviour among Nurses in Lautech Hospital, Osogbo, Osun State. It was recommended that Organisations should sensitize employees to exhibit courteous, conscientious and sportsmanship behaviours by instituting relevant policies, trainings and group discussions.
\end{abstract}

Keywords: Work Engagement, Organisational Citizenship Behaviour, Altruism, Civic Virtue, Sportsmanship, Courteousness, Nurses.

\section{Introduction}

The performance of any organisation depends heavily on the individual and collective performance of its employees. Most especially in a competitive business environment, employees who can perform extra roles to complement stated roles are needed by organisations to survive, grow and expand. Even when bottlenecks are present in business operations, employees who carry out extra roles apart from those specified by the company will complete the given task successfully. Extra-role behaviours portrayed by these employees are known as organisational citizenship behaviour.

Organisational citizenship behaviour means the willingness of employees to go beyond the formal specifications' roles, also known as extra-role behaviours, but had an impact on the performance of the organisation (Ahmed, Rasheed \&Jehanzeb, 2012). It refers to money-making and efficient 
investment with favorable outcomes for individuals, organisations, and society as a whole (Amikhi, 2009). Self-development, helpful behaviour, sportsmanship, and loyalty may all have an influence on a company's survival (Ojebola et. al., 2020). Organisational citizenship behaviour refers to behaviours that are intended to assist colleagues, supervisor or the organisation and include acts such as improving work environment morale, volunteering for work that is no aspect of the job description, as well as recommended improvements in the functioning of the organisation (Daghian, 2016).

According to Rauf (2016), employee behaviours and attitudes have a significant impact on both individual and organisational success. If an employee exhibits organisational citizenship behaviour, it shows the contribution or dedication of employees as organisational citizens. Organisational citizens have persistence, ability, and flexibility to cope with the additional work efforts without any hope of reward in return (Feigin, et. al., 2014). In this case, employees' self-realization and motivation are seen through their dedication and potentiality towards the organisation (Jaksic, 2013).

Several OCB models have been developed by researchers since the origin of the concept, however, there are five dimensions of OCB that are very frequently recognized in existing research (LePine, Erev \& Johnson, 2002) which include altruism, courtesy, civic virtue, sportsmanship, and conscientiousness. Altruism in the workplace consists essentially of helping behaviours that can be directed within or outside of the organisation. Courtesy has been defined as discretionary behaviour that aims at preventing work-related conflicts with other personnel (Law et al., 2005). Civic virtue is characterized by behaviours that indicate the employee's deep concerns and active interest in the life of the organisation (Law et al., 2005). Conscientiousness includes adherence to organisational rules/norms, and it depicts the reliability and dependability of the employee within the organisation. Finally, sportsmanship has been defined as willingness on the part of the employee that signifies the employee's tolerance of less-than-ideal organisational circumstances without complaining and blowing problems out of proportion.

According to Osaro and Akinmayowa (2014), predictors of citizenship behaviour of employees include employees' spirituality, degree of affective commitment, employee's perception of organisational fairness and employee's personality. As noted by Bakker et. al., (2014), work engagement predicts client satisfaction, organisational citizenship behaviour, and task performance. Work engagement is described as enthusiasm, devotion, absorption, and energy in achieving the organisation's goals andobjectivesAnitha (2014). Work engagement is important because recent research findings suggest that engaged employee's practice: happiness, joy, and enthusiasm, good physical and psychological health, better job performance, increased ability to create job and personal different capacity and an ability to transfer their engagement to others (MirzaDarani, 2013). The focus and energy that are characteristics of work engagement allow employees to bring their full potential into the work, Antoinette (2012). Employees, who are engaged in their work, can work long hours and put their heart into their work, but they do not have the characteristics of hard workers Antoinette (2012). 


\section{Statement of the Problem}

Organisational performance has a propensity to decline and be unstable as a result of factors such as political instability, legal factor, rapid technical innovation, intense international rivalry, and unpredictable economic situations. In today's rapidly changing business environment, it has been observed that businesses are confronted with several severe issues. Some of these issues are low employee engagement, unproductive workforce, and abnormal employee workplace behaviour (sluggish work, leaving the office early, not assisting coworkers, complaining about petty issues, taking extended breaks, misusing time and resources, theft, among others). Furthermore, although several studies have demonstrated the value of employee engagement, the proportion of workers who are actively involved in their job is rather low (Maru \& Singh, 2020).

As a result, employers of labour must comprehend, formulate, and implement strategies for employee engagement and organisational citizenship behaviour, which may prove to be a critical component of winning the battle for exceptional performance in today's constantly changing business environment. Moreover, empirical studies showing the relationshipand possible effect between OCB and employee engagement have not been documented in the Lautech Teaching Hospital, Osogbo, Osun State. Against this backdrop, the study explores the relationship between work engagement and OCB in Lautech Teaching Hospital, Osogbo, Osun State. Understanding the scope of the problem will inform policymaking, program creation, and implementation in Nigeria, particularly at the Lautech Teaching Hospital in Osogbo.

\section{Research Hypotheses}

The following hypotheses are formulated for testing the study

1. There is no significant relationship between work engagement and organisational citizenship behaviour among Nurses in Lautech Hospital, Osogbo, Osun State.

2. There is no significant relationship between work engagement and altruism among Nurses in Lautech Hospital, Osogbo, Osun State.

3. Thereis no significant relationship between work engagement and sportsmanship among Nurses in Lautech Hospital, Osogbo, Osun State.

4. There is no significant relationship between work engagement and civic virtue among Nurses in Lautech Hospital, Osogbo, Osun State.

5. There is no significant relationship between work engagement and work conscientiousness among Nurses in Lautech Hospital, Osogbo, Osun State.

\section{LiteratureReview}

\section{Theoretical Review}

\section{Social Exchange Theory}

Saks (2006) has proposed a social exchange theory about employee engagement. This theory provides a hypothetical basis to discuss why employees become more or less engaged in their works. Social exchange theory proposes that obligations are made through a series of interactions between parties who are in a state of reciprocal interdependence. As discussed by AbuKhalifeh and Som, (2013) the basic rule of social exchange theory is that the relationship grows over time into trusting, 
loyal and mutual understanding as long as the parties stand by certain rules of the exchange. Therefore, one effective technique for an employee to pay their organisation is through their level of engagement towards their work (AbuKhalifeh\&Som, 2013).

Saks (2006) argued that the level of engagement of the employees is largely dependent upon the facilities and resources which they receive from their organisation. By making full involvement towards their works and dedicating a higher amount of cognitive and emotional and physical resources is an important way for every employee to respond to the organisational action (AbuKhalifeh\&Som, 2013). When the employees receive resources from their employer, they feel they "owe" the organisation by becoming more engaged and bring themselves more into their works effectively to repay their organisation. When an organisation fails to provide these kinds of resources, employees are more likely to withdraw and disengage themselves from their work. Therefore, all the resources; cognitive, emotional, and physical which an employee brings to their works are provisional on the resources which they receive from their organisation (Kahn, 1990). Thus, employee engagement consists of psychological and emotional connection between employees and organisation that leads to positive or negative performance at work (AbuKhalifeh\&Som, 2013).

\section{Empirical Review}

\section{Organisational Citizenship Behaviour and Work Engagement}

Rurkkhum (2010) in research on employee engagement and five dimensions of organisational citizenship behaviour in Thai organisations found that all four dimensions (altruism, civic virtue, conscientiousness, and sportsmanship) except dimension courtesy of organisational citizenship behaviour indicate positive relation with employee engagement. George and Joseph (2015) studied the connection between employee engagement and OCB on employees working in travel organisations. The outcomes reveal that employee engagement positively influences the OCB.

Owor (2015) researched the relationship between HR practices and OCB with a mediating role of employee engagement in the soft drinks company in Uganda. The study shows that employee engagement is also significantly positively correlated with organisational citizenship behaviour. Furthermore, this study reveals that organisational citizenship behaviour is predicted by five of nine antecedents of HR practices and employee engagement. Also, it shows that employee engagement act as a mediator role in between HR practices and OCB Owor (2015).

Abed and Elewa (2016), studied the relationship between organisational support, work engagement, and organisational citizenship behaviour about the nurses 'perception in different Hospitals. The outcome of this study is that all three constructs of organisational support, employee engagement, and organisational citizenship behaviour positively significantly correlated with each other. Furthermore, the result indicates a positive significant relationship between work engagement and organisational citizenship behaviour. Amadi, et. al. (2017) investigated the association between employee engagement and OCB in Maritime Firms of Nigeria and this study found that employee engagement has a positive significant relationship with organisational citizenship behaviour. This research also confirms that organisational citizenship behaviour can be improved through the appliance of cognitive and emotional engagement between employees in Maritime firms. 
Sahoo, and Mohanty (2019) reviewed the literature on the impact of employee engagement on organisational citizenship behaviour. By using different techniques, the authors demonstrated that there are positive and strong relationships among the dimensions of employee engagement and organisational citizenship behaviour. Future research could pay attention on the extension of dimensions of both organisational citizenship behaviour and employee engagement in different sectors.

Amadi, Seth, and Ojiabo, (2017) investigate the relationship between employee engagement and organisational citizenship behaviour in Maritime Firms in Onne, Rivers State, Nigeria. A cross-sectional research design was adopted. The target population (N-193) consists of management and management trainees. The bivariate analysis was carried out using Spearman rankorder correlation coefficient. The findings of this study reveal that Employee engagement has a positive significant relationship with organisational citizenship behaviour. This study concludes that organisational citizenship behaviour can be enhanced through the application of cognitive and emotional engagement among employees in Maritime firms. The study recommends that organisations must encourage human capital development for effective utilization of the staff and women should be encouraged to be actively involved in the maritime organisations.

Osama (2016) explored the relationship between employee engagement and organisational Citizenship behaviour (OCB) in the Cement industry in Egyptian culture. Osama (2016) investigate the relationship between Employee engagement as an independent construct and OCB as a dependent construct in a private cement company in Egypt. A sample of 350 employees were planned to be used supported by HR group of the Titan cement company in Egypt through using paper and pencil survey which was designed to measure the vigor, dedication, and absorption as an employee engagement dimension, and to measure conscientiousness, altruism, courtesy, sportsmanship, and civic virtue as OCB dimensions without testing any mediating or moderating roles for another construct. Findings suggest that Employee engagement has a direct significant positive relationship with OCB for employees working in the cement industry in Egypt.

\section{Methodology}

The study adopted the survey research method. Specifically, the study utilized the Ex-post factor design. The design is found appropriate because the researcher would not be involved in the manipulation of any variable(s) of interest. The independent variable in the study is work engagement while the dependent variable is organisational citizenship behaviour. The target population for the study would comprise all nurses who work in Lautech teaching hospital, Osogbo, Osun State, Nigeria. According to the hospital administrative department, it was revealed that there are 13 different areas where nurses work in the hospital, with the entire population of nurses in the hospital amounting to 432. A sample size of 207 was determined using the Taro Yamane formula. Participants were selected using stratified and simple random sampling techniques

The main instrument used for the study is a structured questionnaire. Out of the 207 questionnaires distributed to respondents, 150 questionnaires were collected and analysed. The questionnaire consists of thirty-eight (38) statements in which section ' $\mathrm{A}$ ' contains socio-demographic information 
of the respondents; Section 'B' contains information on work engagement. Lastly, section ' $\mathrm{C}$ ' contains information on organisational citizenship behaviour. The Organisational Citizenship Behaviour Scale developed by Podsakoff, MacKenzie, Moorman, and Fetter (1990) was used to measure organisational citizenship behaviour. The questionnaire contains (15) items that were covered by five subscales as follows: conscientiousness (3-items), sportsmanship (3-items), civic virtue (3-items), courtesy (3-items), and altruism (3-items. The coefficient for the scale was 0.89 on Cronbach alpha. Engagement at work has been measured in a variety of ways.

In the current research, the Utrecht Work Engagement Scale (UWES) developed by Bakker, Schaufeli, and Salanova (2006) will be adopted to measure the levels of nurses' engagement in their work roles. The items of the UWES consists of (17-items) are clustered into three subscales corresponding to the conceptual components of work Engagement: Vigor consists of (6 items), Dedication consists of (5 items) and Absorption consists of (6 items). The reliability coefficient for the scale was 0.91 on Cronbach alpha. Descriptive statistics was used to analyse the demographic variables. The inferential statistics was used to test the stated hypotheses. Specifically, the study utilized the statistical test of the Pearson product-moment correlation. The statistical package for social sciences (SPSS) version 22.0 was used utilized for data analysis.

\section{Results}

\section{Frequency Distribution of Respondents Socio-Demographic Characteristics}

The result revealed that $70(46.7 \%)$ of the respondents were male while 80 (53.3\%) were female. 40 (26.7\%) of the respondents were within the age bracket $20-29$ years; 53 (35.3\%) of the respondents were within the age bracket 30-39 years; 43 (28.7\%) of the respondents were within the age bracket $40-49$ years; $12(8.0 \%)$ of the respondents were within age bracket above 50-59 years while $2(1.3 \%)$ of the respondents were within the age bracket 60 years and above. 50 (33.3\%) of the respondents were single; $85(56.7 \%)$ were married; $11(7.3 \%)$ of the respondents were divorced; $2(1.3 \%)$ of the respondents were separated while $1(0.7 \%)$ of the respondent was a widow or widower respectively. 59 (39.3\%) of the respondents were Christians; 73 (48.7\%) were Muslims while 18 (12.0\%) were of other religions, not specified in the study. 21 (14.0) of the respondents were holders of SSCE/NECO/GCE; 31 (20.7\%) of the respondents were holders of Ordinary National Diploma (OND), 60 (40.0\%) were holders of First Degree/Higher National Diploma; 30 (20.0\%) were holders of master's degree while only $8(5.3 \%)$ of the respondents were holders of Professional Certificate. $43(28.7 \%)$ of the respondents had worked between 0-5 years; 57 (38.0\%) of the respondents had worked between 6-10 years; 30 (20.0\%) of the respondents had worked between 11-15 years; 10 $(6.7 \%)$ of the respondents had worked between 16-20 years; 5 (3.3\%) of the respondents had worked between 21-25 years;5 (3.3\%) had worked between 26-30 years while no respondent had worked between 31 years and above.

\section{Hypothesis Testing}

This section is meant for hypothesis testing. In all Five (5) hypotheses were stated and tested as shown below: 
H01: Thereis no significant relationship between work engagement and organisational citizenship behaviour among Nurses in Lautech Hospital, Osogbo, Osun State.

Table 1: A summary table of Pearson $r$ Correlation showing the relationship between work engagement and organisational citizenship behaviour among Nurses in Lautech Hospital, Osogbo, Osun State.

\begin{tabular}{|l|l|l|l|l|l|l|}
\hline \multicolumn{1}{|c|}{ Variables } & \multicolumn{1}{|c|}{$\mathrm{N}$} & \multicolumn{1}{|c|}{$\overline{\mathrm{X}}$} & \multicolumn{1}{|c|}{$\mathrm{SD}$} & $\mathrm{df}$ & $\mathrm{R}$ & $\mathrm{P}$ \\
\hline Work Engagement & 150 & 27.79 & 9.33 & & & \\
\cline { 1 - 5 } $\begin{array}{l}\text { Organisational Citizenship } \\
\text { Behaviour }\end{array}$ & 150 & 32.22 & 13.20 & 148 & .26 & $<.01$ \\
\hline
\end{tabular}

Source: Author's Fieldwork, 2020

The result in table 1 above revealed that there was a significantly positive relationship between work engagement and organisational citizenship behaviour among Nurses in Lautech Hospital, Osogbo, Osun State $[\mathrm{r}(148)=.26 \mathrm{P}<.01]$. Therefore, the hypothesis one was rejected by the result of the study.

$\mathbf{H O}_{2}$ : There is no significant relationship between work engagement and altruism among Nurses in Lautech Hospital, Osogbo, Osun State.

Table 2: A summary table of Pearson $r$ Correlation showing the relationship between workengagement and altruisminLautech Hospital, Osogbo, Osun State.

\begin{tabular}{|l|l|l|l|l|l|l|}
\hline \multicolumn{1}{|c|}{ Variables } & \multicolumn{1}{|c|}{$\mathbf{N}$} & \multicolumn{1}{|c|}{$\overline{\mathbf{X}}$} & \multicolumn{1}{|c|}{ SD } & \multicolumn{1}{c|}{ Df } & \multicolumn{1}{c|}{$\mathbf{\text { r }}$} & P \\
\hline Work Engagement & 150 & 27.76 & 9.32 & & & \\
\hline Altruism & 150 & 5.45 & 3.01 & 148 & $.13^{* *}$ & $<.01$ \\
\hline
\end{tabular}

Source: Author's Fieldwork, 2020

The result in table 2 above revealed that there was a significantly positive relationship between work engagement and altruism among Nurses in Lautech Hospital, Osogbo, Osun State [r $(148)=.13^{* *}$, $\mathrm{P}<.01]$. Therefore, the hypothesis two was rejected by the result of the study.

$\mathbf{H 0}_{3}$ : There is no significant relationship between work engagement and sportsmanship among Nurses in Lautech Hospital, Osogbo, Osun State. 
Table 3: A summary table of Pearson $r$ Correlation showing the relationship between workengagement and sportsmanshipatLautech Hospital, Osogbo, Osun State.

\begin{tabular}{|l|l|l|l|l|l|l|}
\hline Variables & $\mathbf{N}$ & $\overline{\mathbf{X}}$ & SD & Df & $\mathbf{R}$ & $\mathbf{P}$ \\
\hline Work Engagement & 150 & 27.76 & 9.32 & & & \\
\hline Sportsmanship & 150 & 5.18 & 2.44 & 148 & $.74 * *$ & $<.01$ \\
\hline
\end{tabular}

Source: Author's Fieldwork, 2020

The result in table 3 above revealed that there was a significantly positive relationship between work engagement and sportsmanship among Nurses in Lautech Hospital, Osogbo, Osun State [r (148) = $.74 * *, \mathrm{P}<.01]$. Therefore, the hypothesis three was rejected by the result of the study.

$\mathbf{H 0}_{4}$ : There is no significant relationship between work engagement and civic virtue among Nurses in Lautech Hospital, Osogbo, Osun State.

Table 4: A summary table of Pearson $r$ Correlation showing the relationship between workengagement and civic virtueatLautech Hospital, Osogbo, Osun State.

\begin{tabular}{|c|c|c|c|c|c|c|}
\hline Variables & $\mathbf{N}$ & $\overline{\mathbf{X}}$ & SD & Df & $\mathbf{r}$ & $\mathbf{P}$ \\
\hline Work Engagement & 150 & 27.76 & 9.32 & & & \\
\hline Civic virtue & 150 & 5.27 & 2.65 & 148 & $.36^{*}$ & $<.05$ \\
\hline
\end{tabular}

Source: Author's Fieldwork, 2020

The result in table 4 above revealed that there was a significant positive relationship between work engagement and civic virtue among Nurses in Lautech Hospital at Osogbo, Osun State [r (148) = $\left..36^{*}, \mathrm{P}<.05\right]$. Therefore, the hypothesis four was rejected by the result of the study.

H05: There is no significant relationship between work engagement and conscientiousness among Nurses in Lautech Hospital, Osogbo, Osun State. 
Table 5: A summary table of Pearson $r$ Correlation showing the relationship between workengagement and conscientiousness at Lautech Hospital, Osogbo, Osun State.

\begin{tabular}{|c|c|c|c|c|c|c|}
\hline Variables & $\mathbf{N}$ & $\overline{\mathbf{X}}$ & SD & df & $\mathbf{R}$ & $\mathbf{P}$ \\
\hline Work Engagement & 150 & 27.76 & 9.32 & \multirow[b]{2}{*}{148} & \multirow[b]{2}{*}{$.23 *$} & \multirow[b]{2}{*}{$<.05$} \\
\hline Conscientiousness & 150 & 5.24 & 2.34 & & & \\
\hline
\end{tabular}

Source: Author's Fieldwork, 2020

The result in table 5 above revealed that there was a significant positive relationship between work engagement and conscientiousness among Nurses in Lautech Hospital, Osogbo, Osun State [r (148) $\left.=.23^{*}, \mathrm{P}<.05\right]$. Therefore, hypothesis five was rejected by the result of the study.

\section{Discussion of Findings}

The first hypothesis which statedthatthereis no significant relationship between work engagement and organisational citizenship behaviour among Nurses in Lautech Hospital, Osogbo, Osun State was rejected by the result of the study. The result revealed that there isa significant positive relationship between work engagement and organisational citizenship behaviour among Nurses in Lautech Hospital, Osogbo, Osun State. The results of this study corroboratewith the findings of Fatma \&Hebashy (2016) who reported that there was a highly significant correlation between nurses' perception of organisational support, work engagement and citizenship behaviour respectively. Furthermore, findings of this study is in tandem with the finding of the studies of Rurkkhum (2010) who reported that work engagement has a significant relationship with OCB.

The second hypothesis stated that there is no significant relationship between work engagement and altruism among Nurses in Lautech Hospital, Osogbo, Osun State was rejected by the result of the study. The result revealed that there is a significant positive relationship between work engagement and altruism among Nurses in Lautech Hospital, Osogbo, Osun State. This is in line with previous studies by Rurkkhum, (2010); Avey, et. al., (2008). These studies identified a positive relationship statistically among employees in organisation.Altruism is the willingness of an employee to help his colleagues which also include the selflessness of an employee towards his organisation.

The third hypothesis stated that there is no significant relationship between work engagement and sportsmanship among Nurses in Lautech Hospital, Osogbo, Osun State was rejected by the result of the study. The result revealed that there is a significant positive relationship between work engagement and sportsmanship among Nurses in Lautech Hospital, Osogbo, Osun State. Sportsmanship behaviour demonstrates tolerance without complaining in the fewer manners ideal circumstances or not making a big deal out of small matters (Zhang, 2014). More so, sportsmanship behaviours are aimed at maintaining the status quo and enhancing social harmony (Khadija, Mirza, 
\& Sami, 2014). Sportsmanship is also referred to discretionary organisational behaviour which contributes to organisational effectiveness and promotes a highly positive work climate which fosters employee satisfaction (Mushtaq\& Umar, 2015).

Hypothesis four that stated that there is no significant relationship between work engagement and civic virtue among Nurses in Lautech Hospital, Osogbo, Osun State was rejected by the result of the study. The result revealed that there is a significant positive relationship between work engagement and civic virtue among Nurses in Lautech Hospital, Osogbo, Osun State. This finding was in line with the study of (Kim, 2013), the study revealed that work engagement has a positive influence on civic virtue. Furthermore, civic virtue behaviour is seen as a source of social cohesiveness within the workplace which is positively related to work performance (Mustaq\&Umar, 2015).

Finally, hypothesis five which stated that there is no significant relationship between work engagement and work conscientiousness among Nurses in Lautech Hospital, Osogbo, Osun State was rejected by the result of the study. The result revealed that there is a significant positive relationship between work engagement and work conscientiousness among Nurses in Lautech Hospital, Osogbo, Osun State. Conscientiousness refers to dedication to work, aspiration to perform beyond the formal requirements in punctuality and conservation of resources (Khadija, Mirza, \& Sami, 2014). Examples of conscientiousness behaviours include arriving work early and leaving late, being punctual in meetings and appointments, executing tasks on time, managing company resources and making constructive suggestions.

\section{Conclusion}

Based on the findings of the study, it is concluded therefore that:

- Work engagement had a positive and significant relationship with organisational citizenship behaviour among Nurses in Lautech Hospital, Osogbo, Osun State.

- Work engagement had a positive and significant relationship with altruism among Nurses in Lautech Hospital, Osogbo, Osun State.

- Work engagement had a positive and significant relationship with sportsmanship among Nurses in Lautech Hospital, Osogbo, Osun State.

- Work engagement had a positive and significant relationship with civic virtue among Nurses in Lautech Hospital, Osogbo, Osun State.

- Work engagement had a positive and significant relationship with work conscientiousness among Nurses in Lautech Hospital, Osogbo, Osun State.

\section{Recommendations}

Based on the findings of the study, the following recommendations were made:

1. Organisation should as a matter of urgency leverage on OCB as it has potential to increase organisation efficiency by enhancing employee engagement as well as increasing the stability of organisational performance, hence reducing variability.

2. Organisations should encourage human capital development to enhance staff commitment in assisting other staff. Organisations should promote its culture because it leverages employee engagement and organisational citizenship behaviour. 
3. The management should improve and foster positive working relationship among her employees which when systematically established will enhance the performance of the employees thereby ultimately leading to the organisation achieving its goals.

\section{References}

Abed, F., and Elewa, A. H. (2016). The Relationship between organisational support, work engagement and organisational citizenship behaviour as perceived by staff nurses at different hospitals. Journal of Nursing and Health Science, 5(4),113-123.

AbuKhalifeh, A. N., and Som, A. P. M. (2013). The antecedents affecting employee engagement and organisational performance. Asian Social Science, 9(7),41-46. DOI:10.5539/ass.v9n7p41

Ahmed N, Rasheed A, and Jehanzeb K (2012). An exploration of predictors of organisational citizenship behaviour and its significant link to employee engagement. International Journal of Business, Humanities, and Technology. 2 (4), 99-106.

Amadi, B.Z., Seth, A.J and Ojiabo, U., (2017). An empirical study on the relationship between employee engagement and organisational citizenship behaviour in maritime firms, Onne, Nigeria. International Journal of Advanced Academic Research Social \& Management Sciences 3, (2), 16-32

Amikhi, F. (2009). The relationship between empowerment and organisational citizenship behaviour in educational organisations in Qom. MS Thesis, Tehran University, (College of Qom).

Antoinette Ettebargagliotti L. (2012) Work engagement in nursing: a concept analysis. Journal of Advanced Nursing 68(6), 1414-1428. DOI: 10.1111/ j.1365-2648.2011.05859.

Anitha, J. (2014). Determinants of employee engagement and their impact on employee performance. International journal of productivity and performance management, 63(3), 308323.

Avey, J. B., Wernsing, T. S., and Luthans, F. (2008). Can positive employees help positive organization change? Impact of psychological capital and emotions on relevant attitudes and behaviors. The Journal of Applied Behavioral Science, 44, 48-70.

Bakker, A.., Demerouti, E., and Sanz-Vergel, A. (2014) burnout and work engagement: the jd-r approach. Annual Review of Organisational Psychology and Organisational Behaviour, 1(0), 21.

Bakker, A. B., Schaufeli, W., and Salanova, M. (2006). The measurement of work engagement with a short questionnaire: A cross-national study. Educational and Psychological Measurement, 66(4), 701-716. 10.1177/0013164405282471.

Daghian, Z., Esmaily, H., Hooshmand, E., and Sadodin, S., (2016). The Relationship between Organisational Citizenship Behaviour, Job Satisfaction, and Occupational Stress among Midwives Working in Healthcare Centers of Mashhad, Journal of Midwifery Reproduction Health, 4(2),622-630. 
Fatma, A., and Hebashy, E. A. (2016). The relationship between organizational support, work engagement and organizational citizenship behavior as perceived by staff nurses at different hospitals. IOSR Journal of Nursing and Health Science, 5(4), 113-123.

Feigin, S., Owens, G., and Goodyear-Smith, F. (2014). Theories of human altruism: A systematic review. Annals of Neuroscience and Psychology, 1(1), 1-9.

George, G., and Joseph, B. (2015). A study on the relationship between Employee engagement and organisational citizenship concerning employees working in travel organisations. AtnaJournal of Tourism Studies, 10(2), 33-44.

Kahn, W. A. (1990). Psychological conditions of personal engagement and disengagement at work. Academy of Management Journal, 33(4), 692-724. DOI: 10.2307/256287

Khadija, M., Mirza, A., and Sami, W. (2014). A Study on job satisfaction, motivation and organisational citizenship behaviour. International Journal of Management Sciences and Business Research, 3(11), 1-12.

Kim, H. (2013). Transformational leadership, organisational clan culture, organisational affective commitment and organisational citizenship behaviour: A case of South Korea Public sector. Springer Science-Business Media, New York. Public Organisation Review, 14 (3): 397-417.

Law, S. K., Wong, C., and Chen, X. Z. (2005). The construct of organisational citizenship behaviour: Should we analyze after we have conceptualized? In D. L. Turnipseed (Ed.), Handbook of organisational citizenship behaviour (pp. 47-65). New York: Nova Science Publishers.

LePine, J. A., Erez, A., and Johnson, D. E. (2002). The nature and dimensionality of organisational citizenship behaviour: A critical review and meta-analysis. Journal of Applied Psychology, $87,52-65$.

Maru, M. A., and Singh, A. (2020). Employee engagement and organizational citizenship behaviour: A comparative study of public and private insurance sectors in Ethiopia. International Journal of Scientific and Technology Research, 9(4), 568-575.

Mirza Darani, H. (2013). Work engagement towards social hilarity. Journal of Social Sciences, $62,62-70$

Mushtaq, Khadija, and Umar, Muhammad (2015). Association between job satisfaction, motivation and five factors of organizational citizenship behavior. International Journal of Social, Behavioral, Educational, Economic and Management Engineering, 9(8), 2872-2878.

Ojebola, O. O., Osibanjo, A. O., Adeniji, A. A., Salau, O. P., and Falola, H. O. (2020). Organisational citizenship behaviour and its influence on manufacturing firms' survival in Nigeria: A systematic review. Academy of Strategic Management Journal, 19(1), 1-14.

Osaro, I. R., and Akinmayowa, J. T. (2014). The determinants of citizenship behaviour in Nigerian organisations.European Journal of Business and Management, 6(35), 155-167. 
Osama, M.Z, (2016). The relationship between organisational citizenship behaviour and employee engagement in Cement Industry in Egypt. International Journal of Management and Commerce Innovations, 4(1), 362-376.

Owor, J. J. (2015). HR practices and OCB: the mediating role of employee engagement in soft drink firms in Uganda.

Podsakoff, P. M., MacKenzie, S. B., Moorman, R. H., and Fetter, R. (1990). Transformational leader behaviors and their effects on followerse trust in leader, satisfaction, and organizational citizenship behavior. Leadership Quarterly, 1, 107-142.

Rauf, F. A. (2016). Two sides of the same coin: harmful or helpful? A critical review of the consequences of organizational citizenship behavior. Journal of Advance Management and Accounting Research, 3(9)

Rurkkhum, S. (2010). The relationship between employee engagement and organisational citizenship behaviour in Thai organisations.

Sahoo, S. R and Mohanty, S. (2019). Impact of employee engagement on organisational citizenship behaviour: An overview. Revista ESPACIOS, 40 (7), 1-6.

Saks, A. M. (2006). Antecedents and consequences of employee engagement. Journal of Managerial Psychology, 21(7), 600-619. DOI: 10.1108/02683940610690169

Zhang, S. (2014). Impact of job involvement on organisational citizenship behaviour in China. Journal of Business Ethics, 12(2), 165-174. 